\title{
Association of p-phenylenediamine exposure with alterations of pulmonary function, pruritus and health-related quality of life in hair dye manufacturer workers: a cross-sectional study
}

ming zhang ( $\sim$ beckhamdavid@163.com )

Tianjin Centers for Disease Control and Prevention https://orcid.org/0000-0002-2169-0755

Lin Fan

Institute of Environmental Health and Related Product Safty, Chinese Center for Disease Control and Prevention

Meibian Zhang

Zhejiang Provincial Center for Disease Control and Prevention

Baofeng Liu

Tianjin Centers for Disease Control and Prevention

Qiang Zeng

Tianjin Centers for Disease Control and Prevention

\section{Research article}

Keywords: p-Phenylenediamine, Occupational exposure, Pulmonary function, Health-related quality of life, Pruritus

Posted Date: March 25th, 2020

DOI: https://doi.org/10.21203/rs.3.rs-19200/v1

License: (c) (i) This work is licensed under a Creative Commons Attribution 4.0 International License. Read Full License 


\section{Abstract}

Background $\mathrm{p}$-Phenylenediamine (PPD) is a common component of hair dye, indicating the clinical characteristics of skin contact allergy and asthma with impaired pulmonary function. Howerver the adverse effects of PPD occupational exposure was rarely mentioned. The purpose of this study was to explore the PPD-induced pulmonary function, pruritus and healthrelated quality of life (HRQOL) of industrial workers of hair dye. Methods We recruited 124 workers from a hair dye manufacturer exposed to PPD. Individual PPD exposure and pulmonary function of workers were measured. The quality of life and subjective pruritus of workers was also assessed by SF-36 and VAS of pruritus, respectively. Results In the high PPD-exposed group, FVC\% (percentage of forced vital capacity) was higher, while FEV1/FVC\% (ratio percentage of forced expiratory volume) was lower than that in the low PPD-exposed group $(P<0.05)$. In terms of the HRQOL, the scores of mental health and vitality of the high PPD-exposed group were the lowest of all groups $(P<0.05)$, while the score of VAS was significantly higher than that of other two groups $(P<0.001)$. PPD levels were negatively correlated with vitality and mental health $(\mathrm{P}<0.01)$. Higher PPD exposure level was correlated with a significantly higher VAS level $(\mathrm{OR} 9.394 ; 95 \% \mathrm{Cl}$ : $1.710,51.622 ; P=0.010)$. The structural equation model provided a good fit to the data $(X 2 / d f=1.607, G F I=0.901, A G F I$ $=0.934, \mathrm{RMSEA}=0.007, \mathrm{IFI}=0.977, \mathrm{CFI}=0.960, \mathrm{PGFI}=0.615)$. And showed that PPD exposed level have positive effects on VAS level $(\beta=0.213, P<0.001)$. Then PPD exposed level partly via lack total score of SF-36 $(\beta=-0.465, P=0.002)$; on negative effects on VAR level $(\beta=-0.110, P<0.001)$. Conclusion Occupational PPD exposure might be associated with pulmonary function impairment, poor HRQOL, and subjective pruritus of workers.

\section{Background}

p-Phenylenediamine (PPD), a derivative of p-nitroanaline, is found in the plastic and chemical industries as byproducts of manufacturing. Due to its low molecular weight (108 kDa), PPD has a strong protein binding ability to penetrate deeply into the hair. It is widely used as an oxidizable hair dye for its free availability and low cost. In addition, this chemical is used as a substitute for henna and in the manufacturing of rubber and certain polymers. It also acts as a developing agent in color photographic film [1].

PPD is highly toxic with local and systemic toxic effects when taken by mouth, and the outcome depends mainly on the dose taken. Many studies have shown that PPD has multiple organ system toxicity, which can cause skin allergies and itching, cardiotoxicity, and urinary toxicity. Among these health hazards, the most common is the skin toxicity and respiratory damage in low-dose exposure of PPD. In addition, PPD use in hair dyes can lead to skin allergy including severe contact dermatitis, and PPD is considered an important cause of hair dye allergy [2,3].

In 1939, PPD was first defined as a strong allergen and included in the standard antigen group of the North American and European epidermal patch tests. According to European Cosmetic Directive (76/768/EEC), PPD's maximum permissible concentration in hair coloring is $2 \%$. The serious level of PPD allergy is mostly determined by the exposure concentration and duration [4]. It is reported that PPD causes erythema, scaling, itching or edema in less than $1 \%$ individuals of the general population after dying the hair [5]. Occupational exposure to PPD foam, during its production or application in manufacturing of various products, may result in health problems affecting airway and skin. Both allergic contact dermatitis (ACD) and irritant contact dermatitis (ICD) have been reported [6]. The incidence of PPD related ACD, an occupational-related, positive patch test reaction to PPD, is about $4.80 \%$ in outpatients who workers occupational exposed to PPD such as hairdressers, barbers [7]. PPD may also cause damage to the lungs. Induction routines and challenge patches with $0.001-10 \%$ PPD sensitized $56-100 \%$ of guinea pigs on test. Massive peribronchial infiltrates of eosinophils were observed in guinea pigs after intrapulmonary injection of an aqueous solution containing 1\% PPD. Antigen-induced infiltrates were limited to the injected lung, and no eosinophilic infiltrates were detected in the untreated lung, which served as the control [8]. According to European Cosmetic Directive (76/768/EEC), PPD's maximum permissible concentration in hair coloring is $2 \%$. The serious level of PPD allergy is mostly determined by the exposure concentration and duration [9]. It is reported that PPD causes erythema, scaling, itching or edema in less than $1 \%$ individuals of the general population after 
dying the hair [5]. Moreover, long-term occupational exposure to PPD may lead to chronic renal impairment in workers, and the serum creatinine, proteinuria and hematuria were correlated with their working age [10]. Oxidized products of PPD might also have potential carcinogenicity to humans. Association has been observed between hair dye use and non-Hodgkin's lymphoma, multiple myeloma, acute leukemia and bladder cancer $[11,12,13]$.

As aforementioned, occupational exposure to PPD can result in health problems such as skin allergies and pulmonary function changes [7]. These problems may lead to a decline in their quality of life, and then interfere with their activities of daily living and work. However, previous studies have mostly conducted research on ordinary people or emergency patients, and the studies of occupational groups only focused on individual case reports of hairdressers. So far, no research has been conducted on workers who are working on exposure PPD. In addition, there are few studies evaluating the effect of the PPD exposure on the itching of the skin and the quality of life for the workers. In order to evaluate skin discomfort and correlate it with the effects on the individual, there is also a need for methods to determine the clinical severity of people. Compared with patch-test to PPD allergy in previous research, the Visual analogue scale (VAS) could evaluate the skin discomfort without an obvious allergic reaction [7, 14]. And examination including peripheral blood, pulmonary function has been presented as an easily-used method reflecting the physical condition. Health-related quality of life (HRQOL) is a broad and multidimensional measure that assesses an individual's perception of physiological function, mental ability and social adaptability. HRQOL can be influenced by health status, medical interventions, personal beliefs, social environments, economic circumstances and cultural backgrounds [15]. Therefore, another aim of the present study is focused on the dimensions of subjective quality of life by using the short form 36 health survey (SF-36) to evaluate the HRQOL of PPDexposed workers in hair dye production.

\section{Methods}

\subsection{Study Population}

The cross-sectional study was based on data from a hair dye company containing PPD in Zhejiang Province of PR China. The occupational health management in this company is standardized, possessing protective measures that can prevent contact with dangerous substance includes masks, protective clothing, boots and overshoes. The participants were enrolled using a simple random method who are engaged in configuring raw material $(n=9)$, adding chemical $(n=9)$, adding material into the jar $(n=28)$, packaging and transporting $(n=50)$, laboratory staffs $(n=4)$, accounting $(n=6)$, cleaning and logistics $(n=13)$ and managing $(n=5)$. The sample had 68 men and 56 women. All subjects had a convincing history of no

allergic reaction. They were asked to fill out a demographic questionnaire which included the age, gender, area of residence, telephone number, working age, educational status, smoking status and hair dye use status. All participants have signed informed consent, and ethical approval was granted by the Ethics Committee of Tianjin Center for Disease Control and Prevention.

\subsection{Measurement of PPD concentration}

Referenced to the method 5013 of the U.S. National Institute for Occupational and Safety (NOISH) [16], the PPD in the air of various working environments and workers of different types (simple random sampling of $3 \sim 5$ individuals per type of work) were sampled, and then determined samples by high performance liquid chromatography (HPLC) with the analytical column of Eclipse SB-C18 $(150 \mathrm{~mm} \times 4.6 \mathrm{~mm} \times 5 \mu \mathrm{m})$ and the mobile phase of mixed solution of disodium hydrogen phosphate solution and acetonitrile with a flow rate of $2.0 \mathrm{~mL} / \mathrm{min}$. The detection wavelength was $240 \mathrm{~nm}$ and the injection volume was $5 \mu \mathrm{L}$.

\subsection{Self-reported measures of life condition}

The subjects completed two self-reported assessment for life condition: SF-36 and VAS of pruritus. 
The quality of life was assessed by SF-36, derived from the health survey results of the Medical Outcomes Study (MOS) in 1988. It has been translated into Chinese in 1991 and its reliability and validity has been verified in Chinese population after considering cultural adaptation, validation, and normalization [17]. SF-36 measured eight dimensions of health including physical functioning, role-physical, bodily pain, general health, vitality, social functioning, role-emotional and mental health.

In addition to these dimensions, SF-36 also considered reported health transition scaled scores [18]. Each scale was directly transformed into a score from 0 to 100 after modifying the weighing coefficient in each question. The lower score meant the worse health status, whereas the higher the score the less possible disability [19]. The Cronbach's a values for each dimension of SF-36 were calculated to be greater than 0.7 , indicating that the internal consistency of the scale is good in occupational workers. After factor analysis, the KMO value was 0.625 and Bartlett's test result show $P$ value was less than 0.001 , indicating that the structural validity was good. Therefore, this scale had suitable reliability and validity for the occupational population.

The extent of subjective pruritus was assessed by VAS of pruritus [20]. It has been widely used because of a simple structure and flexible operation. Participants could mark a score for a $100 \mathrm{~mm}$ horizontal line on the questionnaire to represent their subjective feelings of cutaneous itching. The benchmark descriptors for each level were as follows: 1 level: $0 \mathrm{~mm}$ to $10 \mathrm{~mm}$ (i.e., no itching symptoms), "no or almost no itch"; 2 level: $10 \mathrm{~mm}$ to $40 \mathrm{~mm}$ (i.e., slight itching symptoms), "occasional restless sensations that do not necessarily induce scratching behavior"; 3 level: $40 \mathrm{~mm}$ to $70 \mathrm{~mm}$ (i.e., moderate itching symptoms), "significant scratching and the itch disrupts sleep, and although the patient can go back into sleep after scratching"; 4 level: more than $70 \mathrm{~mm}$ (i.e., fierce itching symptoms), "unbearable itch causes scratching and scratching almost deprived of sleep, the patient keeps scratching ceaselessly".

\subsection{Biochemical detection}

The levels of alanine transarninase (ALT), aspartate aminotransferase (AST), total protein (TP), albumin (ALB), alkaline phosphatase (ALP), total bilirubin (TBI) in serum were detected using commercial test kits (Jiancheng Bioengineering Ltd., Nanjing, China).

\subsection{Hematologic detection}

Red blood cell (RBC), white blood cell (WBC), hemoglobin (HGB) and platelet (PLT) were detected using commercial test kits (Jiancheng Bioengineering Ltd., Nanjing, China).

\subsection{Pulmonary function examination}

The pulmonary function test was obtained for all workers to evaluate the capacity and the volume of lungs, by forced vital capacity (FVC), forced expiratory volume in one second (FEV1), and ratio of FEV1 to FVC (FEV1/FVC).

\subsection{Statistic analysis}

Statistical analysis was conducted using SPSS package (Version 20.0) unless otherwise specified. Numerical variables were reported as mean \pm SD. The Chi-square test and Chi-square after Yates continuity correction test were used to compare the differences of demographic situation and working age, educational, smoking and hair dye use between different groups. The covariance analysis and Bonferroni test were performed for comparing interesting variables in different groups after controlling for the confounding factors, and $\mathrm{P}<0.017$ (two-tailed)was considered statistically significant, taking the multiple comparisons into consideration. Covariates included gender, nation, working age, education condition and recent hair dye history. Due to the co-linearity of working age and age, this study only adjusted working age as a covariate. Study on the influencing factors of VAS level by logistic regression. Before the multivariate analysis, the Variance Inflation Factor (VIF) was calculated to rule out the effects of multicollinearity. We used logistic regression to estimate the odds ratio (OR) and its $95 \%$ confidence interval $(95 \% \mathrm{Cl})$ for the association of VAS level with hematologic indexes and some factor scores in SF36. $\mathrm{P}<0.05$ \two-tailed $\square$ was considered statistically significant in the final models. Structural equation modeling (SEM), which can evaluate the relationship between variables, was performed with the AMOSE software. Cutoff criteria for good 
model fit were attained from extant literature; Satorra-Bentler $\chi^{2} / \mathrm{df}$ values $<3.0$ were considered good; GFI values $>0.90$ and $\mathrm{AGFI}>0.90$ were considered reasonable; RMSEA values $<0.10$, IFI and $\mathrm{CFI}$ values $>0.90, \mathrm{PGFI}>0.50$ were considered good. $\mathrm{CAIC}_{\text {default }}<\mathrm{CAIC}_{\text {independence }}$ and $\mathrm{CAIC}_{\text {default }}<\mathrm{CAIC}_{\text {saturated }}$ were considered good [21]. Missing data was replaced by means of the scores in the different groups.

\section{Results}

\subsection{General characteristics of investigated population}

According to the PPD exposure concentrations, each worker was divided into three levels ( $1 \mathrm{st} \mathrm{level:}<0.00001 \mathrm{mg} / \mathrm{m}^{3} ; 2 \mathrm{nd}$ level: $0.00001 \sim 0.00033 \mathrm{mg} / \mathrm{m}^{3}$; 3rd level: $0.00033 \varangle 0.047 \mathrm{mg} / \mathrm{m}^{3}$ ). Subsequently, 124 subjects were divided into exposed groups and non-exposed control group, the former further divided into high and low concentration groups of PPD exposure. The non-exposed control group included financial staffs, support staffs, administrative personals and cleaners (< $\left.0.00001 \mathrm{mg} / \mathrm{m}^{3}\right)$. The workers who were involved in raw material, adding chemical, adding material into the jar, and laboratory staffs were designated as the high concentration group $\left(0.00089 \otimes 0.19 \mathrm{mg} / \mathrm{m}^{3}\right)$, while the packaging workers were designated as the low concentration group $\left(0.00001 \sim 0.00089 \mathrm{mg} / \mathrm{m}^{3}\right)$ (Supplemental Table 1).

The distributions of demographic characteristics among the three groups were showed in Supplemental Table 2. High concentration group, low concentration group and control group statistically differed in gender, nation, working age, education condition and hair dye history $(\mathrm{P}<0.05)$. The male constituent ratio was higher in the high concentration group $(82 \%)$ than in the low concentration group (36\%) and the control group (37.5\%). Among the three groups, the proportion of the Han nationality in low concentration group $(80 \%)$ was lower than other groups. The number of workers with working age less than 5 years was the highest in low concentration groups (54\%). In the term of educational condition, the proportion of primary school and lower level was lower in control group than the other two groups. The hair dye history in the control group (16.67\%) had a lower constituent ratio than the high concentration group (54\%).

\subsection{Changes of hematologic indexes of the study participants}

The hematologic indexes results among the three groups were in the normal count ranges. After adjustments for gender, nation, working age, education condition and recent hair dye history, the covariance analysis showed that in the high concentration group, white blood cell count was lower $(P<0.001)$, while basophils and eosinophils were higher $(P<0.05)$ than that in the control and low concentration groups. Besides, compared to the low concentration group, workers in the high concentration group presented a higher neutrophil and hemoglobin level. No differences were observed for other hematologic indexes indices among the three groups (Table 1). 
Table 1

Covariance analysis results of serum biochemical indexes (mean \pm SD)

\begin{tabular}{|c|c|c|c|c|c|}
\hline Variable & $\begin{array}{l}\text { Control } \\
\text { group }\end{array}$ & $\begin{array}{l}\text { Low concentration } \\
\text { group }\end{array}$ & $\begin{array}{l}\text { High concentration } \\
\text { group }\end{array}$ & $\mathbf{F}$ & $\begin{array}{l}\mathrm{P} \\
\text { value }\end{array}$ \\
\hline White blood cell count $\left(10^{9} / \mathrm{L}\right)$ & $\begin{array}{l}6.929 \pm \\
1.243\end{array}$ & $6.656 \pm 1.088^{\#}$ & $5.206 \pm 1.209^{*}$ & 8.569 & $<.001$ \\
\hline Neutrophil(10\%/L) & $\begin{array}{l}3.951 \pm \\
0.914\end{array}$ & $3.423 \pm 0.291^{\star \#}$ & $3.949 \pm 0.911$ & 2.803 & 0.010 \\
\hline Lymphocyte(10\%/L) & $\begin{array}{l}1.839 \pm \\
0.489\end{array}$ & $1.836 \pm 0.480$ & $1.925 \pm 0.541$ & 0.706 & 0.667 \\
\hline Basophils $\left(10^{9} / \mathrm{L}\right)$ & $\begin{array}{l}0.015 \pm \\
0.010\end{array}$ & $0.015 \pm 0.014^{\#}$ & $0.040 \pm 0.015^{\star}$ & 16.053 & $\dot{0} 001$ \\
\hline Monocytes $\left(10^{9} / \mathrm{L}\right)$ & $\begin{array}{l}0.350 \pm \\
0.078\end{array}$ & $0.342 \pm 0.050$ & $0.334 \pm 0.063$ & 0.718 & 0.657 \\
\hline Eosinophils $\left(10^{9} / \mathrm{L}\right)$ & $\begin{array}{l}0.157 \pm \\
0.112\end{array}$ & $0.212 \pm 0.078^{\star \#}$ & $0.363 \pm 0.102^{*}$ & 16.505 & $\dot{0} 001$ \\
\hline Red blood cell count $\left(10^{12} / \mathrm{L}\right)$ & $\begin{array}{l}5.017 \pm \\
0.392\end{array}$ & $5.122 \pm 0.413$ & $5.080 \pm 0.420$ & 0.379 & 0.913 \\
\hline Hemoglobin(g/L) & $\begin{array}{l}142.920 \pm \\
13.247\end{array}$ & $140.780 \pm 12.621^{\#}$ & $148.160 \pm 13.577$ & 13.364 & $\dot{0} 001$ \\
\hline Mean corpuscular volume(fL) & $\begin{array}{l}85.670 \pm \\
10.516\end{array}$ & $86.380 \pm 10.463$ & $85.560 \pm 10.695$ & 0.643 & 0.720 \\
\hline $\begin{array}{l}\text { Mean corpuscular hemoglobin } \\
\text { concentration }(\mathrm{g} / \mathrm{L})\end{array}$ & $\begin{array}{l}340.880 \pm \\
11.449\end{array}$ & $339.540 \pm 8.779$ & $338.400 \pm 7.902$ & 0.756 & 0.625 \\
\hline Mean platelet volume(fL) & $\begin{array}{l}9.370 \pm \\
1.075\end{array}$ & $9.650 \pm 0.497$ & $9.480 \pm 0.945$ & 1.065 & 0.391 \\
\hline Platelet volume distribution width & $\begin{array}{l}11.996 \pm \\
2.146\end{array}$ & $11.770 \pm 1.668$ & $11.796 \pm 1.897$ & 0.849 & 0.549 \\
\hline $\begin{array}{l}\text { The average amount of } \mathrm{Hb} \text { in red } \\
\text { blood cells(pg) }\end{array}$ & $\begin{array}{l}28.920 \pm \\
4.106\end{array}$ & $28.940 \pm 4.043$ & $29.720 \pm 3.552$ & 0.486 & 0.843 \\
\hline Platelet count $\left(10^{9} / \mathrm{L}\right)$ & $\begin{array}{l}234.040 \pm \\
45.108\end{array}$ & $237.940 \pm 45.488$ & $238.320 \pm 43.507$ & 1.105 & 0.365 \\
\hline Plateletcrit(PTC) & $\begin{array}{l}0.271 \pm \\
0.042\end{array}$ & $0.258 \pm 0.042$ & $0.261 \pm 0.045$ & 0.639 & 0.723 \\
\hline \multicolumn{6}{|c|}{${ }^{\star} \mathrm{P}<0.05$,there were statistical differences between exposed groups and control group by Bonferroni method. } \\
\hline \multicolumn{6}{|c|}{$\begin{array}{l}\# \mathrm{P}<0.05 \text {,there were statistical differences between high concentration group and low concentration group by } \\
\text { Bonferroni method. }\end{array}$} \\
\hline
\end{tabular}

\subsection{Alteration of Pulmonary function of the study participants}

After adjustments for gender, nation, working age, education condition and recent hair dye history, the spirometry parameters of the three groups were significantly different. The pulmonary function indices like FEV1\% and FEV1/FVC\% of the high concentration group were significantly lower than those of control group $(P<0.05)$. In the high concentration group, 
FVC\% was higher, while FEV1/FVC\% was lower than that in the low concentration group $(\mathrm{P}<0.05)$. In addition, compared to control group, workers in the low concentration group presented the lower FVC\% and FEV1\% $(P<0.05)($ Table 2).

Table 2

Covariance analysis of FVC\%, FEV1\%, FEV1/FVC\% in different PPD-exposure group (mean \pm SD)

\begin{tabular}{|c|c|c|c|c|c|c|}
\hline Variable & & Control group & $\begin{array}{l}\text { Low concentration } \\
\text { group }\end{array}$ & $\begin{array}{l}\text { High concentration } \\
\text { group }\end{array}$ & $F$ & $\begin{array}{l}\mathrm{P} \\
\text { value }\end{array}$ \\
\hline FVC\% & & $\begin{array}{l}103.044 \pm \\
9.498\end{array}$ & $89.076 \pm 11.806^{\star \#}$ & $101.399 \pm 9.409$ & 7.519 & $\begin{array}{l}< \\
0.001\end{array}$ \\
\hline FEV1\% & $\begin{array}{l}104.665 \pm \\
12.289\end{array}$ & $91.772 \pm 6.261^{*}$ & $92.483 \pm 10.300^{*}$ & 8.791 & $<.001$ & \\
\hline FEV1/FVC\% & $\begin{array}{l}102.215 \pm \\
14.040\end{array}$ & $\begin{array}{l}104.700 \pm \\
14.779^{\#}\end{array}$ & $91.889 \pm 12.737^{\star}$ & 6.855 & $<.001$ & \\
\hline
\end{tabular}

${ }^{*} \mathrm{P}<0.05$, there were statistical differences between exposed groups and control group by using Bonferroni method.

\# $\mathrm{P}<0.05$,there were statistical differences between high concentration group and low concentration group by Bonferroni method.

The covariant variables including gender, ethnic group, working age, education condition and recent hair dye history.

\subsection{Self-reported of physical subjective feelings of the study participants}

After excluding the influence of gender, nation, working age, education condition and recent hair dye history, covariance analysis indicated that means for role-physical $(P=0.023)$, bodily pain $(P<0.001)$, general health $(P<0.001)$, vitality $(P<$ $0.001)$, mental health $(P<0.001)$, health transition $(P<0.001)$ and total scores were all significantly different among the three groups (Table 3 ). The means for bodily pain, general health and health transition in low concentration group were lower than the control group and the high concentration group $(P<0.05)$. Besides, the mean for mental health in the high concentration group and role-physical in the low concentration group was lowest of all groups $(P<0.05)$. High concentration PPD also resulted in a decreased vitality score compared to the control group. For the total score, the score for control group was higher than the exposure groups, and the high concentration group was higher than the low concentration exposure group $(P<0.05)$. 
Table 3

Covariance analysis results of SF-36 (mean \pm SD)

\begin{tabular}{|c|c|c|c|c|c|c|c|c|c|c|}
\hline Variable & $\mathrm{PF}$ & RP & BP & $\mathrm{GH}$ & VT & SF & $\mathrm{RE}$ & $\mathrm{MH}$ & HT & $\begin{array}{l}\text { Total } \\
\text { score }\end{array}$ \\
\hline Control group & $\begin{array}{l}98.13 \\
\pm 2.88\end{array}$ & $\begin{array}{l}96.09 \\
\pm 6.60\end{array}$ & $\begin{array}{l}97.25 \pm \\
8.77\end{array}$ & $\begin{array}{l}92.0 \pm \\
10.62\end{array}$ & $\begin{array}{l}72.08 \\
\pm 9.55\end{array}$ & $\begin{array}{l}92.71 \\
\pm 9.69\end{array}$ & $\begin{array}{l}93.06 \\
\pm 9.08\end{array}$ & $\begin{array}{l}61.5 \\
\pm 5.25\end{array}$ & $\begin{array}{l}85.40 \pm \\
24.36\end{array}$ & $\begin{array}{l}788.32 \pm \\
48.52\end{array}$ \\
\hline $\begin{array}{l}\text { Low- } \\
\text { concentration } \\
\text { group }\end{array}$ & $\begin{array}{l}97.40 \\
\pm 3.81\end{array}$ & $\begin{array}{l}94.88 \\
\pm \\
9.25 \#\end{array}$ & $\begin{array}{l}83.60 \pm \\
21.01^{*} \#\end{array}$ & $\begin{array}{l}78.4 \pm \\
13.93^{\star} \#\end{array}$ & $\begin{array}{l}65.30 \\
\pm \\
14.16\end{array}$ & $\begin{array}{l}91.20 \\
\pm \\
12.94\end{array}$ & $\begin{array}{l}95.83 \\
\pm 8.29\end{array}$ & $\begin{array}{l}59.04 \\
\pm \\
6.18 \#\end{array}$ & $\begin{array}{l}59.50 \pm \\
19.49^{\star} \#\end{array}$ & $\begin{array}{l}725.29 \pm \\
47.11^{\star} \#\end{array}$ \\
\hline $\begin{array}{l}\text { High- } \\
\text { concentration } \\
\text { group }\end{array}$ & $\begin{array}{l}98.50 \\
\pm 2.31\end{array}$ & $\begin{array}{l}96.87 \\
\pm 5.54\end{array}$ & $\begin{array}{l}97.37 \pm \\
5.23\end{array}$ & $\begin{array}{l}88.20 \pm \\
16.96\end{array}$ & $\begin{array}{l}62.30 \\
\pm \\
11.91 *\end{array}$ & $\begin{array}{l}87.25 \\
\pm \\
15.04\end{array}$ & $\begin{array}{l}94.3 \\
\pm \\
10.84\end{array}$ & $\begin{array}{l}55.12 \\
\pm \\
8.68 *\end{array}$ & $\begin{array}{l}72.50 \pm \\
22.73\end{array}$ & $\begin{array}{l}752.45 .32 \\
\pm 47.52^{*}\end{array}$ \\
\hline $\mathrm{F}$ & 1.276 & 2.444 & 8.972 & 6.983 & 5.51 & 1.632 & 0.617 & 4.477 & 6.163 & 3.780 \\
\hline $\mathrm{P}$ & 0.268 & 0.023 & $<0.001$ & $<0.001$ & $\begin{array}{l}< \\
0.001\end{array}$ & 0.133 & 0.741 & $\begin{array}{l}< \\
0.001\end{array}$ & $<0.001$ & 0.026 \\
\hline
\end{tabular}

${ }^{*} \mathrm{P}<0.05$,there were statistical differences between exposed groups and control group by Bonferroni method.

\# $\mathrm{P}<0.05$,there were statistical differences between high concentration group and low concentration group by Bonferroni method.

SF-36: the short form 36 health survey; PF: physical functioning; RP: role-physical; BP: body pain; GH: general health; VT: vitality; SF: social functioning; RE: role-emotional; $\mathrm{MH}$ : mental health; $\mathrm{HT}$ : health transition.

The covariant variables including gender, ethnic group, working age, education condition and recent hair dye history.

The results of multivariable logistic regression analysis for VAS levels with some demographic variables, SF-36 factors were showed in Table 4. It found that men were less likely to present high VAS levels than women (OR 0.114, 95\% Cl: 0.027, 0.482, $\mathrm{P}=0.003)$. The worker who works in a high concentration PPD atmosphere significantly increased the probability of VAS level (OR 9.394, 95\% Cl: 1.710, 51.622, $\mathrm{P}=0.010)$. Individuals without a hair dye history had almost one tenth the probability of not (OR 0.091, 95\% Cl: 0.021, 0.385, P = 0.001). And workers with senior middle school and higher education have lower level of VAS (OR 0.041, 0.033 respectively; both $\mathrm{P}<0.05)$. As for SF-36 scores, workers with the higher BP score have higher VAS level (OR 1.056, 95\% Cl: 1.008, 1.106, P = 0.021), and with higher $\mathrm{GH}$ score have lower VAS level (OR 0.950, 95\% Cl: $0.904,0.998, P=0.040)$. 
Table 4

Multiple Logistic regression analysis of VAS level with hematologic indexes and some factor scores in SF-

\begin{tabular}{|c|c|c|c|c|c|c|}
\hline & $\beta$ & $s_{x}^{\prime}$ & Wald $\chi^{2}$ & $P$ value & OR & $95 \% \mathrm{Cl}$ \\
\hline Intercept & 8.271 & 5.182 & 2.548 & 0.110 & & \\
\hline \multicolumn{7}{|l|}{ PPD exposed levels } \\
\hline Control $=0$ & & & & & 1 & \\
\hline Low $=1$ & 0.230 & 0.893 & 0.066 & 0.797 & 1.259 & $(0.219,7.240)$ \\
\hline High = 2 & 2.240 & 0.869 & 6.640 & 0.010 & 9.394 & $(1.710,51.622)$ \\
\hline Working age & 0.031 & 0.042 & 0.553 & 0.457 & 1.031 & $(0.951,1.119)$ \\
\hline \multicolumn{7}{|l|}{ Gender } \\
\hline Female $=0$ & & & & & 1 & \\
\hline Male $=1$ & -2.170 & 0.735 & 8.721 & 0.003 & 0.114 & $(0.027,0.482)$ \\
\hline \multicolumn{7}{|l|}{ Hair dye history } \\
\hline Yes $=0$ & & & & & 1 & \\
\hline No $=1$ & -2.399 & 0.737 & 10.598 & 0.001 & 0.091 & $(0.021,0.385)$ \\
\hline \multicolumn{7}{|l|}{ Ethnic group } \\
\hline Han $=0$ & & & & & 1 & \\
\hline Others $=1$ & -1.648 & 0.874 & 3.555 & 0.059 & 0.192 & $(0.035,1.067)$ \\
\hline \multicolumn{7}{|l|}{ Educational condition } \\
\hline Primary school and lower level = 1 & & & & & 1 & \\
\hline Junior high school level = 2 & -1.242 & 1.127 & 1.214 & 0.271 & 0.289 & $(0.032,2.632)$ \\
\hline Senior middle School level = 3 & -3.197 & 1.337 & 5.718 & 0.017 & 0.041 & $(0.003,0.562)$ \\
\hline College and higher level = 4 & -3.418 & 1.544 & 4.904 & 0.027 & 0.033 & $(0.002,0.675)$ \\
\hline \multicolumn{7}{|l|}{ SF-36 } \\
\hline $\mathrm{RP}$ & -0.034 & 0.047 & 0.519 & 0.471 & 0.967 & $(0.883,1.059)$ \\
\hline BP & 0.055 & 0.024 & 5.337 & 0.021 & 1.056 & $(1.008,1.106)$ \\
\hline $\mathrm{GH}$ & -0.052 & 0.025 & 4.206 & 0.040 & 0.950 & $(0.904,0.998)$ \\
\hline VT & -0.007 & 0.031 & 0.051 & 0.821 & 0.993 & $(0.935,1.054)$ \\
\hline $\mathrm{MH}$ & -0.008 & 0.042 & 0.038 & 0.845 & 0.992 & $(0.914,1.076)$ \\
\hline HT & -0.017 & 0.015 & 1.389 & 0.239 & 0.983 & $(0.955,1.012)$ \\
\hline
\end{tabular}

\subsection{Structural equation model for SF-36, VAS level and PPD exposed concentrations}

A model with PPD exposed level predicting VAR level through SF-36 scores evidenced reasonable fit across indices (Table 5). All indicators meet the reasonable reference value of the model $\left(\chi^{2} / \mathrm{df}=2.215, \mathrm{GFI}=0.901, \mathrm{AGFI}=0.927, \mathrm{RMSEA}\right.$ 
$=0.092, \mathrm{IFI}=0.972, \mathrm{CFI}=0.969, \mathrm{PGFI}=0.593)$. The model with standardized path coefficients is presented in Supplemental Fig. 1. Direct paths were significant, PPD exposed level have positive affect on VAS level $(\beta=0.213, P<0.001)$. Then PPD exposed level partly via lack total score of SF-36 $(\beta=-0.465, P=0.002)$; on negative affect on VAR level $(\beta=-0.110, P<$ 0.001). The indirect path of hair dye history has negative affect on VAS level $(\beta=-0.221, P=0.002)$, and PPD exposed levels via white blood cell count $(\beta=-0.952, P<0.001)$, basophils $(\beta=0.015, P<0.001)$, eosinophil $(\beta=0.110, P<0.001)$ and hemoglobin $(\beta=3.349, P=0.036)$ were all significant $(P<0.001)$, while neutrophil was nonsignificant $(\beta=0.080, P=0.388)$. In the model, the indirect paths of PPD exposed level via pulmonary function indices showed FEV1\% $(\beta=-5.051, P<0.001)$ and FEV1/FVC\% $(\beta=-6.333, P<0.001)$ were significant, while FVC was nonsignificant $(\beta=1.188, P=0.418)$. The model with standardized path coefficients is presented in Supplemental Fig. 1.

Table 5

Summary of model fit

\begin{tabular}{|lcccccccc|}
\hline Adaptability index & $\chi^{2} / \mathrm{df}$ & GFI & AGFI & RMSEA & IFI & CFI & PGFI & CAIC \\
\hline Reference value & $1-3$ & $>0.90$ & $>0.90$ & $<0.10$ & $>0.90$ & $>0.90$ & $>0.50$ & $\begin{array}{l}\mathrm{CAIC}_{\text {default }}<\text { CAIC }_{\text {independence }} \\
\text { and CAIC }\end{array}$ \\
\hline Modefault & & & & & & & CAIC $_{\text {saturated }}$ \\
& 2.29 & 0.901 & 0.934 & 0.099 & 0.979 & 0.907 & 0.593 & $\begin{array}{l}488.056<1432.971 \\
\text { and } 890.503<890.503\end{array}$ \\
\hline
\end{tabular}

\section{Discussion}

In our study, pulmonary function index like FEV1/FVC\% were lower in high PPD concentration group, and FVC\% was lower in low PPD concentration group than other two groups. In terms of the HRQOL, mental health and vitality of the high PPDexposed group were the lowest of all groups $(P<0.05)$, while the score of VAS was significantly higher than that of other two groups $(P<0.001)$. Higher PPD exposure level was correlated with a significantly higher VAS level $(0 R$ 9.394; $95 \% \mathrm{Cl}$ : $1.710,51.622 ; \mathrm{P}=0.010)$. Occupational PPD exposure might be associated with pulmonary injury, poor HRQOL, and subjective pruritus of workers.

According to the define of health in the World Health Organization, the quality of workers' life is focused not just on the condition of no diagnosed diseases, but on the life [15]. We use two ways for assessing an individual's quality of life; selfadministered questionnaire and physiological health examination. The physiological health examination including peripheral blood and pulmonary function. It evaluates the factors that affect an individual's health such as diseases, which affects life quality. The self-administered questionnaire assesses the complex reaction environmental factors such as pruritus subjectively, pressure and working environment that affect the life quality.

Frequent contact with hair dyes production and working in the atmosphere with PPD aerosol can caused widespread health issues such as contact allergy [22]. In the present study, the blood biochemical indices, pulmonary function, HRQOL and VAS of pruritus were compared among the workers who exposed to different concentrations of PPD aerosol. The results of air monitoring suggested that the mean concentration of PPD in different workshops were lower than the threshold-limited value-time-weighted average $\left(0.1 \mathrm{mg} / \mathrm{m}^{3}\right)$. It puts pressure on the human body health. The workers exposed in high PPD concentration showed a lower white blood cell count and higher basophils, hemoglobin and eosinophils counts. An elevation of basophils, hemoglobin and eosinophils counts was similar to those found in neutrophilic dermatitis, apart from the pronounced eosinophilia. Numerous studies have reported that is a marker of hypersensitivity [23, 24, 25]. Moreover, the results of the present work agreed with most findings of the Sieben's study that both PPD and its auto-oxidation product can stimulate lymphocyte proliferation $[26,27]$.

In our study, both FEV1\% and FEV1/FVC\% were lower in high PPD concentration group, and FVC\% was lower in low PPD concentration group than other two groups. In addition, the mean of all groups' indices were in the normal range. The

Page 10/15 
reason may cause this situation was that the hazard of low PPD dose with long-term exposure was relatively weaker. Some case report researches have also indicated that PPD poisoning could lead to respiratory distress [28, 29]. However, these studies have not reported the effects of low PPD concentration on pulmonary function in the workplace. This finding implied that there might be an increased risk of respiratory disorders for workers in response to long-term PPD exposure.

Any health problems can cause a disruption in the normal life and have a substantial impact on the quality of life [30], it seems important to assess the non-organ-specific manifestations such as HRQL. In the present study, we found that not only body pain, mental health and physical role were affected, but also the general health, vitality and reported health transition were affected for all workers. It has been suggested that these effects can have a long term effect of the acquisition of personality and health behaviors. Our results were similar to the conclusions reached by Mohammadi et al., who studied the HRQL of silica-exposed workers [31]. Various studies have showed that age is a risk factor to physical health status [32,33], because elders were usually affected by one or more chronic diseases and conditions [34]. However, the present study showed that the general health status, vitality and health transition were better in longer work-age workers. It might be explained by the healthy worker effect phenomenon that older workers usually have better health conditions than the general population $[35,36]$. People exposed in high PPD levels have lower score in the dimensions of vitality and mental health. One reason for the results might because they engaged in different types of work that caused different PPD exposed concentration. The other reason for this could be the different ways to select subjects, with studies in this field based on retrospective analysis. The present study proved that smoking was harmful to physical role,it was similar to the previous studies [37, 38]. The current study found that subjective feelings of bodily pain, mental health, and general health are not the same for men and women. As reported by previous study, general health and mental health were significantly associated with gender [9].

In the light of the itching of skin seen as a subjective discomfort, the VAS of pruritus was used in this survey. The results of VAS levels in this survey are related to PPD exposed levels. A similar tendency was found that PPD is responsible for the majority of the allergic reactions to permanent hair color, among which the most common kind of allergic reactions is itchy [39]. It found that women were more likely to feel itching of skin than men. This is partly due to the physiological sensitivity of different gender to PPD. While gender distribution varies among different types of work, we suggest to interpret the presented data considering this gender bias. Because VAS level is also affected by subjective perception, we analyze the impact of health-related quality of life and education condition on VAS level. It found that the higher the level of education, the lower the degree of itching. This may because that a high level of education will have a more comprehensive understanding of the dangers of PPD. The reciprocal and intricate relationship between the psyche and itch has been widely studied [40]. The augmentation of perception of itch owing to the interplay of psychogenic and emotional factors has been well studied [41]. Although pruritus itself is not recognized as a separate entity as such, DSM-V (Diagnostic and Statistical Manual of Mental Disorders, 5th edition by American Psychiatric Association) has already included a category of physical symptoms and related disorder. Pruritic conditions exacerbate the symptoms of itching [42]. Itching and pain have the same receptors and have much in common [43]. Therefore, there is a certain relationship between the degree of body pain and VAS level.

We found direct paths from PPD exposure level to VAS level outcomes through one variable: lack of SF-36. Specifically, have hair dye history predicted negative affect on VAS level. PPD exposed may cause FEV1\% and FEV1/FVC\% decreased, and some pressure to blood biochemical index such as white blood cell count, eosinophils, basophils and hemoglobin. The model provided a good fit to the data. Taken together, structural equation model results support the above hypothesis study, and provides with a possible causal relationship between these variables.

There are several strengths of our study. A key strength of our study is that we first studied the workers with the occupational exposure of PPD as the research object, and measured the levels of occupational exposure to PPD in groups. Therefore, the exposure grouping in this study is more accurate and reasonable. An additional strength of our study is the comprehensively consider the physical and mental health of workers. The physical examination indicators and health-

Page $11 / 15$ 
related quality of life of workers exposed to PPD were analyzed, and a structural equation model was established to establish possible causality. We provide scientific basis for proposing the PPD occupational exposure control level to protect the health of the occupational population.

There are some limitations in this study. First, the study is a cross-sectional study. Although a possible causal association has been established through structural equation modeling, further cohort studies and experimental studies are needed to verify these association. Secondly, the study was limited by its small sample size. Thus, large-scale studies seem necessary in PPD occupational exposed workers to gain a better understanding of the physiological and mental state of the workers. Moreover, there were different types of confounding factors for SF-36 scores and VAS levels: the socio-economic status, income, work type, and stress for life, therefore, further comprehensive studies should consider these factors.

Although there is no relatively safe and effective raw material composition that can completely replace PPD during its production or application in manufacturing of various products, the hazard and risk due to PPD emphasize the needs for multifaceted measures to decrease exposure. It is necessary to put forward protective measures and programs for workers with occupational exposure to PPD.

\section{Conclusion}

Our current study showed that occupational PPD exposure was associated influences on HRQL in workers. PPD exposure levels affect the degree of itching through a partial mediation of health-related quality of life. The means of vitality and mental health were negatively associated with PPD exposure. Workers who exposed to high levels of PPD may cause changes in blood biochemical indicators such as lower white blood cell count and higher basophiles, hemoglobin and eosinophils counts. In response to PPD exposure, workers might have an increased risk of respiratory disorders. Occupational PPD exposure has an effect on subjective itching and health-related quality of life. And health-related quality of life mediates the effects of PPD exposure on subjective pruritus.

\section{Abbreviations}

ACD, allergic contact dermatitis; FEV1, forced expiratory volume in one second; FEV1\%, percentage of forced expiratory volume in one second; FVC\%, percentage of forced vital capacity; FEV1/FVC \%, ratio percentage of forced expiratory volume in one second /forced vital capacity; HRQOL, health-related quality of life; HPLC, high performance liquid chromatography; ICD, irritant contact dermatitis; MOS, the Medical Outcomes Study; OR, odds ratio; PPD, p-Phenylenediamine; SF-36, the 36item Short Form Health Survey; SEM, structural equation modeling $\mathbb{V}$ VAS, Visual analogue scale; VIF, variance inflation factor; BP (bodily pain); GH (general health); RP (role-physical); MH (mental health); VT (vitality); HT (health transition); VAS (Visual analogue scale); SF-36 (36-item Short Form Health Survey).

\section{Declarations}

Ethics approval and consent to participate

All participants have signed informed consent, and ethical approval was granted by the Ethics Committee of Tianjin Center for Disease Control and Prevention.

Consent for publication

Not applicable.

Competing interests

The authors declare that they have no competing interests.

Page 12/15 
Funding

This work was supported by the National Occupational Health Standard Projects of China $(20110207,20140704$, 20192003).

Authors contributions

All authors contributed to the development of this manuscript (LF, MZ, MBZ, BFL and QZ). MZ contributed to the study design. LF, MZ, MBZ, BFL and QZ participate in the investigation, measurements and data collection. LF and QZ conducted the data analysis. LF rafted the original manuscript. MZ reviewed and edited the manuscript. All authors revised and approved the final manuscript.

Acknowledgements

The authors would especially like to thank the participants of the work.

\section{References}

1. Rojanapo W, Kupradinun P, Tepsuwan A, Chutimataewin S, Tanyakaset M. Carcinogenicity of an oxidation product of $p$ phenylenediamine. Carcinogenesis. 1986;7(12):1997-2002.

2. Koopmans AK, Bruynzeel DP. Is PPD a useful screening agent? Contact dermatitis. 2003;48(2):89-92.

3. Lee JY, Kim CW, Kim SS. Analysis of the results from the patch test to para-Phenylenediamine in the TRUE test in patients with a hair dye contact allergy. Ann Dermatol. 2015;27(2):171-177.

4. Pot LM, Coenraads PJ, Goebel C, Blomeke B. Assessment of the elicitation response in subjects weakly sensitized to $p$ phenylenediamine. Br J Dermatol. 2015;172(1):138-144.

5. Krasteva M, Bons B, Ryan C, Gerberick GF. Consumer allergy to oxidative hair coloring products: epidemiologic data in the literature. Dermatitis. 2009;20(3), 123-141.

6. Coulter EM, Jenkinson C, Farrell J, Lavergne SN, Pease C, White A, Aleksic M, Basketter D, Williams DP, King C, Pirmohamed M, Park BK, Naisbitt DJ. Measurement of CD4+ and CD8+ T-lymphocyte cytokine secretion and gene expression changes in p-phenylenediamine allergic patients and tolerant individuals. J Invest Dermatol.

2010;130(1):161-174.

7. Kieć-Swierczynska M, Krecisz B, Swierczyńska-Machura D. Contact allergy to paraphenylenediamine: a 10-year observation held in the Nofer Institute of Occupational Medicine, Lódź. Med Pr. 2007;58(3):215-222.

8. Max Samter MD. Early eosinophilia induced in guinea pigs by intrapulmonary injection of antigenic determinants and antigens. Allergy. 1970;45(4):234-248.

9. Pang J, Cao YL, Zheng YX, Gao NY, Wang XZ, Chen B, Gu XF, Yuan W, Zhang M, Liu T, Zhan HS, Shi YY. Influence of pain severity on health-related quality of life in Chinese knee osteoarthritis patients. Int J Clin Exp Med. 2015;8(3):44724479.

10. Hamdouk M, Abdelraheem M, Taha A, Cristina D, Checherita IA, Alexandru C. The association between prolonged occupational exposure to paraphenylenediamine (hair-dye) and renal impairment. Arab J Nephrol Transplant. 2011;4(1):21-25.

11. Gago-Dominguez M, Bell DA, Watson MA, Yuan JM, Castelao JE, Hein DW, Chan KK, Coetzee GA, Ross RK, Yu MC. Permanent hair dyes and bladder cancer: risk modification by cytochrome P4501A2 and N-acetyltransferases 1 and 2. Carcinogenesis. 2003;24(3):483-489.

12. Sangrajrang S, Renard H, Kuhaprema T, Pornsopone P, Arpornwirat W, Brennan P. Personal use of hair dyes-increased risk of non-Hodgkin's lymphoma in Thailand. Asian Pac J Cancer Prev. 2011;12(9):2393-2396. 
13. 't Mannetje A, De Roos AJ, Boffetta P, Vermeulen R, Benke G, Fritschi L, Brennan P, Foretova L, Maynadié M, Becker N, Nieters A, Staines A, Campagna M, Chiu B, Clavel J, de Sanjose S, Hartge P, Holly EA, Bracci P, Linet MS, Monnereau A, Orsi L, Purdue MP, Rothman N, Lan Q, Kane E, Costantini AS, Miligi L, Spinelli JJ, Zheng T, Cocco P, Kricker A. Occupation and Risk of Non-Hodgkin Lymphoma and Its Subtypes: A Pooled Analysis from the InterLymph Consortium. Environ Health Perspect. 2016;124(4):396-405.

14. Thyssen JP, Andersen KE, Bruze M, Diepgen T, Giménez-Arnau AM, Gonçalo M, Goossens A, Le Coz C, McFadden J, Rustemeyer T, White IR, White JM, Johansen JD. $p$-Phenylenediamine sensitization is more prevalent in central and southern European patch test centres than in Scandinavian: results from a multicentre study. Contact dermatitis. 2009;60(6):314-319.

15. The WHOQOL Group. The World Health Organization Quality of Life assessment (WHOQOL): position paper from the World Health Organization. Soc Sci Med. 1995;41(10):1403-1409.

16. DHHS (NIOSH), NIOSH Skin Notation (SK) Profile $p$-Phenylene Diamine [CAS No. 106-50-3]. https://www.cdc.gov/niosh/docs/2011-154/pdfs/2011-154.pdf?id=10.26616/NIOSHPUB2011154 (access 17.07.20). 2011.

17. Li L, Wang HM, Shen Y. Chinese SF-36 Health Survey: translation, cultural adaptation, validation, and normalisation. J Epidemiol Community Health. 2003;57(4):259-263.

18. Ware JE Jr, Sherbourne CD. The MOS 36-item short-form health survey (SF-36). I. Conceptual framework and item selection. Med Care. 1992;30(6):473-483.

19. McHorney CA, Ware JE Jr, Lu JF, Sherbourne CD. The MOS 36-item Short-Form Health Survey (SF-36): III. Tests of data quality, scaling assumptions, and reliability across diverse patient groups. Med care. 1994;32(1):40-66.

20. Wahlgren CF, Ekblom A, Hägermark O. Some aspects of the experimental induction and measurement of itch. Acta Dermato Venereol. 1989;69(3):185-189.

21. Hu L, Bentler PM. Cutoff Criteria for Fit Indexes in Covariance Structure Analysis: Conventional Criteria versus New Alternatives. Structural Equation Modeling A Multidisciplinary J, 1999;6(1),1-55.

22. Schubert S, Lessmann H, Schnuch A, Uter W, Geier J. Factors associated with p-phenylenediamine sensitization: data from the Information Network of Departments of Dermatology, 2008-2013. Contact dermatitis.2018;78(3):199-207.

23. Augusto de Oliveira L, Mallozi MC, Sole D, Freitas Dd, Sousa LB, Mannis MJ.. Are cutaneous hypersensitivity tests to inhalant allergens a severity marker for vernal keratoconjunctivitis? Arq Bras Oftalmol. 2007;70(6):991-995.

24. Kanerva L, Hyry H, Jolanki R, Hytönen M, Estlander T. Delayed and immediate allergy caused by methylhexahydrophthalic anhydride. Contact dermatitis. 1997:36(1):34-38.

25. Kim MH, Jung JW, Kang HR. The usefulness of job relocation and serum eosinophil cationic protein in baker's asthma. Int Arch Allergy Immunol. 2013;161(3):252-257.

26. Sieben S, Kawakubo Y, Al Masaoudi T, Merk HF, Blömeke B. Delayed-type hypersensitivity reaction to paraphenylenediamine is mediated by 2 different pathways of antigen recognition by specific alphabeta human T-cell clones. Allergy Clin. Immunol. 2002;109(6):1005-1011.

27. White JM, Kullavanijaya P, Duangdeeden I, Zazzeroni R, Gilmour NJ, Basketter DA, McFadden JP. p-Phenylenediamine allergy: the role of Bandrowski's base. Clin Exp Allergy. 2006;36(10):1289-1293.

28. Bhargava P, Matthew P. Hair dye poisoning. J Assoc Physicians India. 2007;55:871-872.

29. Sik G, Citak A. Fatal paraphenylenediamine poisoning due to black henna.

30. Turk J Pediatr. 2016;58(3):301-304.

31. Ormel J, Lindenberg S, Steverink N, Vonkorff M. Quality of life and social production functions: a framework for understanding health effects. Soc Sci Med. 1997;45(7):1051-1063.

32. Mohammadi H, Farhang Dehghan S, Golbabaei F, Roshani S, Pakzad R, Foroughi P, Hajizadeh R. Pulmonary Functions and Health-Related Quality of Life among Silica-Exposed Workers. Tanaffos. 2017;16(1):60-67. 
33. Gunasekara FI, Carter K, McKenzie S. Income-related health inequalities in working age men and women in Australia and New Zealand. Aust N Z J Public Health. 2013;37(3):211-217.

34. Ilmarinen J. Towards a Longer Worklife: Ageing and the Quality of Worklife in the European Union. Finnish Institute of Occupational Health, , 2006;52(1):143-147.

35. Kessler RC, Greenberg PE, Mickelson KD, Meneades LM, Wang PS. The effects of chronic medical conditions on work loss and work cutback. J Occup Environ Med. 2001;43(3):218-225.

36. Li CY, Sung FC. A review of the healthy worker effect in occupational epidemiology. Occup Med(Lond). 1999;49(4):225229.

37. Chowdhury R, Shah D, Payal AR. Healthy worker effect phenomenon: revisited with emphasis on statistical methods - a review. Indian J Occup Environ Med. 2017;21(13):2-8.

38. Kiyohara K, Itani Y, Kawamura T, Matsumoto Y, Takahashi Y. Changes in the SF-8 scores among healthy non-smoking school teachers after the enforcement of a smoke-free school policy: a comparison by passive smoke status. Health Qual Life Outcomes. 2010;8:44.

39. Tran TT, Yiengprugsawan V, Chinwong D, Seubsman SA, Sleigh A. Environmental tobacco smoke exposure and health disparities: 8-year longitudinal findings from a large cohort of Thai adults. BMC Public Health. 2015;15:1217.

40. Diepgen TL, Naldi L, Bruze M, Cazzaniga S, Schuttelaar ML, Elsner P, Goncalo M, Ofenloch R, Svensson Å. Prevalence of Contact Allergy to p-Phenylenediamine in the European General Population. J. Invest. Dermatol. 2016;136(2):409-415.

41. Jafferany M, Davari ME. Itch and psyche: psychiatric aspects of pruritus. Int J Dermatol. 2019;58(1):3-23.

42. Weisshaar E, Diepgen TL, Bruckner T, Fartasch M, Kupfer J, Lob-Corzilius T, Ring J, Scheewe S, Scheidt R, Schmid-Ott G, Schnopp C, Staab D, Szcepanski R, Werfel T, Wittenmeier M, Wahn U, Gieler U. Itch intensity evaluate din German Atopic Dermatitis Intervention Study (GADIS): correlations with quality of life, coping behavior and SCORAD deverity in 823 children. Acta Derm Venereol. 2008;88(3):234-239.

43. Yosipovitch G, Goon A, Wee J, Chan YH, Goh CL. The prevalence and clinical characteristics of pruritus among patients with extensive psoriasis. Br J Dermatol. 2000;143(5):969-973

44. Liu Q, Tang Z, Surdenikova L, Kim S, Patel KN, Kim A, Ru F, Guan Y, Weng HJ, Geng Y, Undem BJ, Kollarik M, Chen ZF, Anderson DJ, Dong X. Sensory neuron-specific GPCR Mrgprs are itch receptors mediating chloroquine-induced pruritus. Cell.2009;139(7):1353-1365.

\section{Supplementary Files}

This is a list of supplementary files associated with this preprint. Click to download.

- SupplementalMaterials.doc

- SupplementalFigure1.tif 